\title{
Taliban insurgency and transnational organized crime nexus
}

\section{Pemberontakan Taliban dan perhubungan kejahatan transnasional terorganisir}

\author{
Mohammad Ayub Mirdad \\ Department of International Relations, Faculty of Social and Political Sciences, Universitas Airlangga \\ Address: Jalan Dharmawangsa Dalam, Airlangga, Surabaya, East Java 60286 \\ E-mail: mohammad.ayub.mirdad-2016@fisip.unair.ac.id
}

Article History: Received 4 September 2019; Accepted 3 May 2020; Published Online 31 August 2020

\begin{abstract}
Afghanistan has been demolished by more than three decades of the ongoing war since the war against the Soviet Union started in 1979. The Afghanistan-Pakistan region provides a geographically secure location and a space of opportunity for organized crime and terrorist groups. This paper aims at exploring the Taliban nexus with organized crime groups in Afghanistan and the region through Makarenko's crime-terror continuum theory. The method of this study is qualitative through the descriptive-analytical approach. The growing connection between insurgents and organized crime poses essential challenges to the region. Each group has developed both criminal and terrorist elements while not relinquishing its original organizing principle. Afghanistan is a war-torn country and weak governance, terrorism, narcotics, illegal mining, poor border control, and widespread corruption provide the perfect opportunity for convergence of the Taliban with organized criminal and insurgent groups in the region. The Taliban and organized crime groups are involved in kidnapping for ransom, drug trade, extortion, and exploitation of natural resources. The finding indicates that, although the objectives of the insurgent and organized crime organizations differ widely, these enabling variables are also suitable for organized crime organizations. The primary objective of organized crime is to gain profit, and the objective of the insurgent is to contest the state power and promote political change through violence. The economic sources are the primary main reason why the two organizations converge.
\end{abstract}

Keywords: insurgents; organized crime; drug trafficking; convergence

\begin{abstract}
Abstrak
Afghanistan telah dihancurkan oleh lebih dari tiga dekade perang yang sedang berlangsung, sejak perang melawan Uni Soviet yang dimulai pada tahun 1979. Wilayah Afghanistan-Pakistan menyediakan lokasi yang secara geografis aman dan ruang peluang bagi kejahatan terorganisir dan kelompok-kelompok teroris. Tulisan ini bertujuan untuk mengeksplorasi hubungan Taliban dengan kelompok-kelompok kejahatan terorganisir di Afghanistan dan wilayah melalui teori kontinum-teror-kejahatan Makarenko. Metode penelitian ini adalah kualitatif, melalui pendekatan analitik deskriptif. Meningkatnya hubungan antara pemberontak dan kejahatan terorganisir menimbulkan tantangan penting bagi wilayah tersebut. Setiap kelompok yang telah mengembangkan unsur-unsur kriminal dan teroris sementara tidak melepaskan prinsip pengorganisasian aslinya. Afghanistan adalah negara yang dilanda perang dan pemerintahan yang lemah, terorisme, narkotika, penambangan ilegal, kontrol perbatasan yang buruk, dan korupsi yang meluas memberikan peluang sempurna bagi konvergensi Taliban dengan kelompok-kelompok kriminal dan pemberontak yang terorganisir di wilayah tersebut. Taliban dan kelompok kejahatan terorganisir terlibat dalam penculikan untuk tebusan, perdagangan narkoba, pemerasan, dan eksploitasi sumber daya alam. Temuan menunjukkan bahwa meskipun tujuan dari organisasi pemberontak dan kejahatan terorganisasi sangat berbeda, variabel-variabel pendukung ini juga cocok untuk organisasi kejahatan terorganisir. Tujuan utama kejahatan terorganisir adalah untuk mendapatkan keuntungan, dan tujuan pemberontak adalah untuk melawan kekuatan negara dan mempromosikan perubahan politik melalui kekerasan. Sumber ekonomi adalah alasan utama mengapa kedua organisasi bertemu.
\end{abstract}

Kata kunci: pemberontak; kejahatan terorganisir; perdagangan narkoba; konvergensi

\section{Introduction}

The terrorism and organized crime connection in the region between Afghanistan and Pakistan has been more reliable than anywhere else. Afghanistan has been destroyed by more than three decades of the ongoing war since the war against the Soviet Union that started in 1979 (Goepner 2018). The 
Afghanistan-Pakistan region provides a geographically secure location and a space of opportunity for organized criminals and terrorists. Corruption is widespread, borders are permeable, the rule of law is very poor or non-existent, and parallel economies have extended over time, simultaneously fueled by conflict and drugs. Kidnapping for ransom, drug trade, taxation, and extortion all provide criminals and terrorists with possibilities to finance their organizations, and criminal networks enable each to include particular nodes within the supply chain (Peters 2012). The Taliban cooperate with the Haqqani network from time to time to gain short-term objectives. Even though the network is a component of the insurgency, it also works as an organized crime group, driven by revenues and pride, vengeance and religion (Peters 2012).

In recent decades, law enforcement, military, and intelligence communities worldwide have witnessed changes in the conduct of organized criminal organizations and terrorist groups. In more decentralized networks with powerful capacities in many offenses, this change has witnessed vertically integrated hierarchical organizations concentrating on profit or political (or religious) ideology (Antonoglou 2018). Experts and scholars recognize that terrorism is not a static danger but an evolving, vibrant menace (Reitano et al. 2017). Recent developments have motivated scholars to move to a more modern understanding of insurgencies from the classic paradigms of terror.

The difference between terrorism and organized crime is based on their goals and techniques. Terrorist organizations are generally those who deliberately challenge the state's power and pursue political change through violence (or the threat of violence) and ideological reasons. Terrorist groups see mobilizing funds as a tool to attain their objectives, rather than the objective itself. On the other hand, organized criminal groups are not seeking political change, but are more interested in profit. As well, any state disruption is designed for the advantage of their activities to generate, stretch, or retain circumstances. Unlike terrorist groups that usually follow political or ideological shifts, organized criminal groups seek the eventual economic and material benefit of their operations (Reitano et al. 2017). While these theoretical distinctions mark organized crime and terrorism, these differences may not be as evident as reinforcing each other's activities. Terrorists may participate immediately or indirectly in the economic and material benefits from criminal operations, such as weapons, drugs, and antiquities trafficking, extortion, ransom kidnapping, and illicit trafficking in natural resources and gems. Such advantages assist terrorist groups to undermine state security, stability, social and economic development, which, in turn, can generate or sustain prosperous circumstances for organized criminal groups (Reitano et al. 2017).

According to Kilcullen (2006) the classical theory of insurgency believes an insurgent contestant to be legitimate, yet perhaps weak. Such insurgencies function from regional or geographic sanctuaries allowing them to reassemble and resupply. Contemporary insurgency concept and counter-insurgency theory recognize modernization of insurgencies that involves globalization (Gilmore 2011), the diversification of financial sources (Kilcullen 2006), and adopting terrorist tactics to ease opposition to state occupation instead of revolution (Bergen \& Footer 2008, Kilcullen 2009). The theory of contemporary counter-insurgency remains to address sanctuaries, though it differentiates overseas sanctuaries from electronic sanctuaries like the internet (Kilcullen 2006). Sanctuaries, encouraged by insurgent collaboration and worldwide terrorist activities (Gilmore 2011 \& Kilcullen 2006), involve political, cultural, financial, and army networks to prolong conflicts (Hammes 2005). Significantly, sanctuaries also enable insurgents to dangerously combine crime and terror by insurgents, recognized as the crime-terror nexus. Consequently, this nexus has assumed a higher significance for research and comprehension.

The significance provided to the crime-terror nexus is appropriate; there are dangerous threats to national and global security anywhere they occur to co-exist interactions between criminals and terrorists. As Makarenko (2004) stated, the consequent threat to security constituted by the crimeterror nexus is a 'black hole' country in which a single organization involved in organized crime and terrorism can affect the flourishing propagation circumstances without fear of consequences from governmental authorities. For instance, the Taliban as a single organization which is deeply involved 
in terrorism and organized crime activities and has a well-built relationship with various insurgent and organized crime groups. Numerous scholars consider this black hole state in the crime-terror literature (Innes 2007 \& Korteweg 2008).

In the literature, there is a discussion on meanings and proper interpretations of concepts such as 'convergence,' 'transformation,' and 'hybrid.' Some conceptualizations of the crime-terror connection relate to a condition in which a solitary organization is growing functional capacities of organized crime and terror as one of 'transformation' (Dishman 2001, Hutchinson \& O'Malley 2007). Most crime-terror researchers who favor this transformation utilize the word 'convergence' to define a condition whereby two organizations, criminal and terrorist group, merge into one hybrid entity (Dishman 2005, Shelley \& Picarelli 2005).

\section{Research Method}

This study's method is qualitative, through the descriptive analytical approach; the reality will be studied very precisely, as we will identify the reasons that led to the occurrence of the relationship of the Taliban with organized crime groups in Afghanistan. The study employs various suitable methods of data collection that helps in a systematic evaluation of data sources. As such, this study draws on secondary data. The study is based on document analysis and library research as a secondary data collection method and analysis of previous studies undertaken by other researchers. These sources include books, e-books, previously published articles, newspapers, and various research reports. Other secondary sources, including the published documents and reports by local and international NGOs, are also collected. Given the critical security situation in Afghanistan, the author was unable to reach an interview with the members of the Taliban (i.e. insurgents) to reflect their opinion in this research.

\section{Result and Discussion}

The issue of the nexus between organized crime groups and terrorism is not a new phenomenon. Particularly in the age of globalization and the advancement of technology, it has provided a wide range of opportunities for the groups, as mentioned earlier. The findings of the study indicate that the conflicts that result from the weakness of the central government provide a reasonable basis for the emergence of organized criminal groups and terrorism. In addition to the human catastrophe inside the country, it becomes a safe place for organized criminal groups and terrorism. Also, the active presence of terrorism and organized crime groups in the region, widespread corruption, drug trafficking, poor governance, and inferior border control, aggravated relations between the Taliban and organized criminal groups. One of the essential factors in the relationship between these two groups is the economic element that supports their activities and collaborations.

\section{Globalization and the drug trade}

Globalization has its advantages and disadvantages and has significant impacts in all areas. Thus, globalization's negative aspects are the growth and expansion of terrorism and organized crime groups; thus, the advances in technology, ease of access to the internet, and the development of easy trade are among the benefits of globalization. Therefore, globalization has made cooperation between terrorism and organized crime groups broader and more accessible, which has led to the continuation of the activities and cooperation of these groups.

According to Stares (1996) drug trafficking has gradually turned into an increasingly transnational force and player as a consequence of globalization. The primary beneficiaries of economic integration and liberalization were debatably global criminal organizations. Subsequently, the global dissemination of technical knowledge and manufacturing internationalization has provided the possibility of cultivating and delivering drugs in remote areas of the globe and remaining accessible to distant economies. Not just expanding trade, transport networks, tourism, but also the expansion of individual movement, mass media development, in particular, worldwide telecommunications and the increasing global financial system integration have given possibilities for money laundering, and investment in other licit or illicit operations and have rendered it simpler for drug traffickers (Stares 1996). 
Globalization is a reality that has benefits and disadvantages, it has a dark side, in other words. It has developed hopeless circumstances, environmental degradation, acute underdevelopment, civil strife, civil conflict, terrorism, unemployment, and the existence of poverty in many areas of the globe as a result of overpopulation (Durnagol 2009). In the production sector, drug management is a lucrative and straightforward financial motivation for individuals residing under these circumstances to develop and generate narcotics because of livelihoods in which few alternatives exist. Subsequently, globalization has permitted legitimate businesses and transnational organized crime groups to equally benefit from the following factors: improved interdependence between nations, the effectiveness of international travel and global communications, the permeability of national borders, and the globalization of international financial systems (Williamson 1996). Thus, there has been an expansion in transnational commerce as information, money, physical goods, and other commodities passage freely across states (Lyman \& Potter 2011).

\section{The Taliban and organized crime activities in Afghanistan}

The Taliban's background of religiously motivated terrorism is well-documented. The Taliban taught and enforced Al-Qaeda's preferred strategies while sheltering Al-Qaeda leaders in Afghanistan. These include the use in both Afghanistan and Pakistan of suicide bombers and Improvised Explosive Equipment (IEDs) (Rashid 2010). The activities of the Taliban in Afghanistan continue to use violence to advance the ideological agenda of their movement. North Atlantic Treaty Organization (NATO) coalition forces, the Afghan National Army, and ordinary civilians are still targets of the lethality of the Taliban (Crilly 2013). The widespread violence in Afghanistan is an instance of the models and ways of the Taliban's choice as they seek to remove threats to their extreme ideology.

The Taliban are similarly skilled at organized crime, although well-established in religious terror. The participation of the Taliban in the trade-in opium and heroin had occurred since the mid-1990s when they came to power in Afghanistan. Afghanistan has become a feudal system for the Taliban, for which opium and heroin are the sources of existence (Rashid 2010 \& Schmidt 2005). The Taliban's participation in the trade in drugs, particularly opium and heroin, is a significant component of their identity and the threats to national and international security. However, it is essential to recognize that their interests in organized crime have become more diverse and prominent. The Taliban, warlords and their soldiers, with control of the profitable trade and commerce corridors, regularly collects taxes for each shipment that passes through their territory (Acharya et al. 2009 \& Reese 2016).

The features of Taliban structured, organized crime in Afghanistan are now diversification and professionalism. With a fully integrated resistance movement concentrated singularly on controlling their native nation, the Taliban included a closely linked and intersecting network of organized criminals capable of generating enormous revenue from entirely different sources. The Taliban involvement in organized crime in Afghanistan is described as follows:

\section{Kidnapping for ransom}

The dependence of the Taliban on ransom kidnapping as a type of income creation can be attributed back to the mid-2000s and continues to this day. Kidnapping is a method used by the Taliban to recover captured members and retain global reputation. Government employees, Non-Government Organizations (NGOs), foreign lecturers of universities, private sector staff working on government projects, and sometimes even journalists are among the targets of Taliban kidnapping (Giustozzi 2009). For example, after Kabul released five Taliban prisoners for the exchange of a journalist at the Italian government's request, the Italian government was able to secure reporter Daniele Mastrogiacomo. The prisoners' release had other consequences in Afghanistan for counter-insurgency attempts, when Mullah Mansur Dadullah, who was one the prisoners released in this exchange, announced he had taken on the function of his slain brother for organizing Taliban activities (Sarwari \& Crews 2009). In another incident, following the kidnapping of 23 South Koreans in 2007 in Afghanistan, the Taliban were able to gain concessions and ransom from the South Korean government (Sang-Hun 2007). South Korea has confirmed it will no longer allow its missionary groups to travel to Afghanistan and reportedly 
paid US\$20 million to the Taliban for the release of 19 remaining hostages (Sang-Hun 2007). In 2008, Tariq Azizuddin, Pakistan's ambassador to Afghanistan, was kidnapped, one of the most politically embarrassing occurrences. It is reported that the Pakistani government freed 55 Taliban operatives and paid for the release of the ambassador with several hundred thousand dollars (Roggio 2008).

\section{Extortion and taxation}

The Taliban derives income from coercion, unlawful taxation, extortion, local asset seizure, and compelled conscription. These techniques are mostly used in Afghanistan's southern and eastern regions and the Federally Administered Tribal Areas (FATA) of Pakistan, where the state is weak. The Taliban establishes illegitimate 'customs points' at the border to charge every person and vehicle passing. Furthermore, the Taliban gets petrol from fuel stations, wheat from peasants as a tithe, and imposes a fixed charge on traders (Khattak 2012).

In addition, alms (zakat) and tithe (ushr) Islamic taxes are a significant source of Taliban funding collection. State or international development projects are primarily subject to taxation and extortion since the resources for these projects are considered capable of misuse, but profitable local companies were also targeted. These taxes, like the protection of drug manufacturing, support local Taliban, and generate an income flow sent to the Taliban chain of command to the Taliban leadership (Weir \& Azamy 2015). According to the Afghan Zariza (2015) the Taliban are engaged in illegal mining directly or acquire forced extortions from mining permission holders and receive about US\$14 million annually. The report also shows that the Taliban directly receives two-thirds of the Chromite mine in Paktika Province of Afghanistan, and, since 2005, they have earned US\$16 million ransom from releasing of foreign hostages, who were mostly Westerners.

\section{Drug trafficking}

The Taliban is deeply involved in the drug industry, and it is the primary source of revenue. In relation to working with narco-traffickers, the Taliban are entering the supply chain in Afghanistan at every point of the narcotics trade (cultivation, production, and trafficking). The group relies upon drug revenues for the recruitment and payment of foot soldiers. More than ever, the Taliban are engaged in the systematic promotion, financing, organization, and protection of the drug trade. The poppy trade has performed a critical part in the Taliban's revival since the U.S.-led invasion of Afghanistan in 2001 (Peters 2009). Since 2001, Taliban actors have improved their profiting methods from drug trafficking as opium production has expanded significantly in lawless areas of the south.

\section{Taliban nexus with organized crime groups}

Terrorist crimes exist today as a challenging phenomenon in various regions of the world and are always at odds with governments and people in the region. In addition to the inability and weakening of the ruling power, hostile interventions by other countries and bad governance, are also other essential factors in protecting the financial interests of terrorists that they gain through their convergence with organized criminal groups. They use these benefits to continue their criminal and banditry activities and maintain their leaders' welfare. With the wars' prolongation, these groups have created a mechanism to generate incredible income through their criminal activities (Nizam 2018). All the groups with nexus with the Taliban are involved either in organized crime or insurgency activities in the region.

According to Makarenko (2004) the Crime-Terror Nexus tends to converge with each other in the form of a continuum of crime and terror organizations. The countries secretly used to finance various terrorist groups around the globe before September 11, 2001. However, the state treasury's financial assistance has now considerably decreased due to the War on Terror. The terrorist groups, for the accumulation of their income, started to engage in criminal operations. The relationship is both structural as well as functional. Criminals and terrorists work together, provide each other with technical help, expertise, arms, and cash, and sometimes they participate directly in each other's operations (Makarenko 2004). Consequently, there is a perfect chance for an evil relationship 
between terrorists and criminal organizations. In the case of the Taliban, they are the largest insurgent organization in Afghanistan, and they have built a relationship and involvement with every insurgent and criminal groups in Afghanistan and the region.

As Peters (2010) has stated, insurgent groups on both sides of the Afghan-Pakistan frontier function as a vast network of criminal groups, not only in terms of the activities they carry out, but also in the way the groups organize, how funds stream through their chain of command, and how they communicate. Criminal profits fund a broader insurgency in this complex adaptive system, while terrorist violence enables insurgents to force and exert a level of control over local communities. Local power brokers, the Taliban, and other insurgent organizations are engaged in and protect organized crime in the sphere of poor governance, rampant state corruption, and predation (Peters 2010).

According to Peters (2010) organized crime facilitates insurgents across the region between Afghanistan-Pakistan to raise funds, and, whether by design or by accident, has effectively turned into a crucial component of their asymmetrical war campaign increased fear and insecurity. Crime reduces the step of development and disappoints efforts to expand the rule of law and build a maintainable legal economy. The insurgents are seeking to legitimatize criminal conduct as part of their jihad, claiming, for instance, that they live from people's alms, or rationalize that they are dealing with drugs to make infidels addicts (Peters 2010). The participation of the Taliban in organized crime is expanding the coalition and the government of Afghanistan' security challenges. However, the economic reliance of the insurgency on predation has also established strategic responsibility, restricting the group's popular appeal and causing intense internal competition. These two weaknesses could be exploited by the coalition and the wider community trying to stabilize Afghanistan, but only in an environment where the Afghan government is viewed as a more reliable alternative (Peters 2010).

Organized crime in post-2001 Afghanistan has presumed a significant destabilizing function. Protecting and taxing drug trafficking assisted funding the Taliban revival, and deepened the Afghanistan conflict by bringing significant wealth and access to explosives and weapons to both insurgents and corrupt state actors. Kidnapping, attacks on security forces, and comprehensive protection rackets have also considerably increased security and other expenses for the coalition, local authorities and international organizations operating in the region, slowing the development, reconstruction, and expanding the claim that Afghanistan's government is weak and ineffective (Peters 2010). The development projects and companies that safeguard insurgents, and then use the money to purchase explosives and attack Afghan National Army, civilians, and international forces, generate a moral danger for the international community and adds to a self-sustaining conflict. In the areas where local people gain from the opium trade, Taliban protection of illicit commerce can obtain various forms of cooperation and support from civilians.

For terrorists and organized crime groups, Afghanistan has become a kind of 'safe haven'. The connection between the Taliban and drug trafficking is a well-known reality for many experts and, in many instances, has been proven. Terrorist groups are supporting the Taliban and have a direct connection with drug traffickers. As Rollins \& Wyler (2013) pointed out, "The Taliban is an instance of an insurgent organization engaged in a vast terrorist activity that has formed alliances with criminal networks". This convergence of the Taliban with organized criminal groups and insurgent groups has led to the prolongation of Taliban insurgency in Afghanistan.

Analysis of the Taliban nexus with organized criminal groups is based on the convergence to support the existence of both groups' activities. They are deeply involved in terrorist and criminal activities inside Afghanistan and the region, like the Pakistani Taliban (Tehrik-i-Taliban Pakistan, or TTP), challenging mainly the Pakistani government, but also supporting the Taliban in Afghanistan. Some TTP militants are reported to be operating on the Afghan part of the border from sanctuaries in Talibancontrolled regions. TTP advantages from drug trafficking in North Waziristan, where cars are stolen, and drug convoys passing the frontier between Pakistan and Afghanistan are charged protection fees (Peters 2010). They also are known to carry out these criminal activities in Pakistan's Khyber 
Pakhtunkhwa, Bajaur, and Oraksai Agencies and Khost province of Afghanistan, where they operate alongside the Haqqani and Al Qaeda Networks (UNODC 2009). There is some adequate evidence that the Afghan Taliban and Pakistani Taliban in these provinces participate in drug production and trafficking (Peters 2010).

According to Peters (2010) the Haqqani Network is an Islamist militant organization operating in the south-eastern region of Afghanistan and the northwestern Federally Administered Tribal Areas (FATA) in Pakistan; the Haqqani network is deeply involved in terrorist and criminal activities, has close relations with the Pakistani Taliban and Afghan Taliban and works with the organization in criminal activities, including trafficking, kidnapping, and extortion in Khost Province of Afghanistan, Northwest and North Waziristan Pakistan (Peters 2010). Most benefits from drug trafficking are produced by taxing the opium trade in southern Afghanistan, particularly in Afghanistan's Helmand and Kandahar provinces. Pakistan's Inter-Services Intelligence retains an alliance with the Haqqani Network and utilizes the network in talks with the Taliban to promote Pakistan's goals. The link between the Haqqani Network and the Taliban is noteworthy, as both organizations are incredibly vicious and highly criminalized to remain as partners for both the Taliban and the Haqqanis (Peters 2010).

Uzbekistan's Islamic Movement (IMU) became a significant drug courier in the 1990s in Afghanistan (Felbab-Brown 2010). The IMU is an Islamic extremist organization that has been involved in Kyrgyzstan, Tajikistan, and Uzbekistan in insurgencies and military attacks. Under the leadership of the Taliban and Al-Qaeda, the IMU is also attacking coalition forces in Afghanistan. The relocation of the IMU to Afghanistan was demonstrated as essential for the expansion of the group. It led to the development of its mission from involving only Uzbekistan to battling against all Central Asian countries, motivating militants from all Central Asian states to enter the IMU (Blua 2004). To facilitate drug trafficking from Afghanistan to Central Asia and beyond, the IMU is also playing an essential role.

Uzbekistan's Islamic Movement favored secure sanctuaries in Taliban-controlled land and backed army operations by the Taliban. Possibly one of the most insecure provinces in northern Afghanistan is Takhar province and the only one in which international insurgent organizations tax the drug trade (UNODC 2011). The Taliban and the IMU control the province's north and certain southern parts. In these areas, the IMU links with ethnic Tajiks and Uzbeks have enabled Taliban assistance to enter the area's heroin trafficking paths by obtaining border control with Tajikistan and, in exchange, the IMU also supports the Taliban operations in Afghanistan.

\section{Theoretical analysis}

In the post-Cold War Era, the criminal and the terrorist groups have been born as evil twins. They have framed a multifaceted connection best depicted as the 'nexus.' A momentous convergence of interest between the criminal and terrorist groups has occurred in the post-9/11 era. Before this incident, the states used to finance the terrorist groups secretly (Makarenko 2004). After the Global War on Terror, economic assistance halted as a result of the US pressure on those states. As a result, terrorist groups have fallen on alternate sources of income; crime has the potential to feed them. In this way, an unholy nexus has been created between crime and terror. The criminals and the terrorists work together, provide technical assistance, expertise, weapons, and cash to one another; and sometimes are directly involved with one another's activities (Makarenko 2004).

As a consequence of the Cold War, the line that differentiated organized crime terrorism has turned out to be obscure. An examination led by Shelly et al. in Daase (2010) presumed that the collaborations between terrorist groups and organized crime networks are becoming further and more complex, sharply contrasting the prevalent belief that the two entities differed in terms of motivations only. After the end of the Cold War, the impending rise of globalization meant that terrorist groups could no longer depend on state sponsorship to fund their operations and were constrained to turn to criminal activities for financial support. The essential purpose behind terrorist groups to hold on to organized 
crime as their primary source of funding is the similar characteristics that the two enterprises share. These similitudes between the two empower them to effectively uphold each other's organizational and operational aspects (Dishman 2001, Makarenko 2004, \& Sanderson 2004.

After 9/11, notwithstanding, the confluence between the terrorist and criminal groups turned out to be progressively and more frequent (Hutchinson \& O'Malley 2007). The "Global War on Terror" has vanished 'traditional' funding sources of terrorism, such as banking, individual donations, and charities (Wang 2010). As a result, terrorist groups are progressively engaged in drug trafficking, robberies, extortion, kidnapping, arms trading and smuggling to obtain financial and material support (Hutchinson \& O’Malley 2007, Meierrieks \& Schneider 2016, Wang 2010).

In the literature on terrorism, the connection between acts of terrorism and acts of crime is known as the crime-terror nexus (Makarenko 2004, Shelley \& Picarelli 2002). The shared factor in the crime-terror nexus is the utilization of violence (or threat thereof) to advance illegitimate objectives (Makarenko \& Mesquita 2014). As indicated by Hutchinson and O'Malley (2007), the crime-terror nexus may incorporate organized and sporadic crime. An essential commonality between organized crime and terrorism alludes to broad organizational ability (Makarenko \& Mesquita 2014), albeit with different objectives (Sanderson 2004, Shelley \& Picarelli 2002). Terrorists use criminal activities to support their political or ideological ends, while organized criminals take part in terrorist activities to maximize illegal profit (Hutchinson \& O’Malley 2007). As indicated by Makarenko's analytical development of a security continuum, terrorist and organized crime groups interact, intersect and overlap in various ways, from strategic participation to complete convergence, which makes it hard to draw a line among criminal and terrorist motivations (Makarenko 2004).

Regarding transnational crime, mostly rely on the viewpoint of Tamara Makarenko, with crime and terror being on a continuum in which, theoretically, they would converge and make an alliance at the central point (Makarenko 2004). The author contends that it is challenging to distinguish profit and ideology-based organizations because they exist on the same plane in which collaboration between criminals and terrorists can occur quickly (Makarenko 2004). According to Makarenko (2004) in evaluating the different relationships that have developed between criminally and politically motivated groups, there are four particular focuses on the continuum of crime and terror. The purposes of cooperation between organized crime and terrorism are divided into four general groups: 1) alliances; 2) operational motivations; and 3) convergence and the 'black hole.' This relationship may exist for the short or long term as long as both partners mutually benefit from such collaboration (Makarenko 2004). Makarenko (2004) has written widely about the connection between criminal groups and terrorist organizations and the types of activities each of these actors engage in to accomplish their objectives. Crime flourishes and terror prevails in a society where the state apparatus is weak. Plenty of criminal groups and insurgent groups are operating in the region and Afghanistan, and there is a probability of joint effort in their activities. For various reasons, their interests converge, and it also appears that they are cohabiting in a cooperative relationship. Crime feeds terrorism. On the other hand, terrorism nourishes crime.

The crime-terror nexus by Makarenko (2004) stated that the two groups share similar characteristics and, due to the financial interest between the two groups, they have made alliances for their survival. The author has also discussed the unstable situation of Afghanistan and endemic corruption, poor border security, and lawlessness. Terrorism and organized crime groups have formed a mechanism to generate incredible revenue through terrorist and criminal activities (Makarenko 2004). The absence of control of the borders by the weak government has led the country has become a haven for terrorism and organized crime groups; they support each other in fighting against the Afghanistan government and coalition forces.

\section{Conclusion}

The essence of the relationship between terrorism and organized crime is generally political. It attempts to tackle this occurrence stay mostly tactical and defensive as a result of the local framework and political economy, with responses mainly driven by law enforcement objectives. While such 
reactions are undoubtedly essential, they lack the authority to tackle the leading causes of the growing interconnected positions between organized criminals and terrorist groups. In other words, such interferences have so far failed to tackle why there is increasing interconnection between terrorists and organized criminals. Afghanistan is well-known for cultivating and producing illicit narcotics and is the world's largest producer of illegal opium and cannabis. In the cultivation, production, distribution, and sale of illicit narcotics, the Taliban is directly or indirectly involved. However, besides the narcotics, there is an equally thriving shadow economy that revolves around illegal mining precious stones like emeralds, collecting illegal taxes, kidnapping for ransom, extortion, smuggling, and increasingly minerals and ores such as chromite, coal, gold, iron all which have become critical illicit sources to the Taliban and organized crime groups.

While the scope and objectives of terrorism and organized crime organizations differ extensively, these enabling variables are also appropriate for organized crime organizations. The primary objective of organized crime is profit gain, but economic funds are essential for terrorism. This commonality is the main reason for the convergence of the two groups. Organized crime, and the drug trade in specific, has dramatically exacerbated, extended, and reshaped the Afghanistan conflict. The expansion of organized crime nexus with insurgent groups on both sides of the Afghanistan-Pakistan frontier demonstrates the vulnerability of conflict zones to this phenomenon, stressing the need for a comprehensive strategy in such an environment that works for the simultaneous implementation of security, development, and the rule of law.

These findings indicate that the Taliban convergence with other insurgents and organized crime groups in Afghanistan and the region is deeply developed. Because of the weak governance, the Afghanistan-Pakistan region provides a geographically secure location and a space of opportunity for organized criminals and terrorists. Here is rampant corruption, permeable borders, the rule of law is weak or non-existent in most areas, and parallel economies have evolved, each driven by war and drugs. Accurately, two characteristics render the growth of insurgents and organized crime more prominent in Afghanistan than elsewhere, both in range and effect. The first is the magnitude and establishment of the illegal economy that emerged during the war. The second is that state institutions and the Afghan National Army are weak to counter the insurgents and criminal groups. Therefore, Afghanistan needs a stable government that has such characteristics to counter the terrorism and organized criminal groups, fight corruption, establish the rule of law, strengthening security forces, strengthening control of borders, securing absolute sovereignty and countering impunity and social marginalization, in addition to the cooperation of neighboring countries, particularly Pakistan, in the fight against terrorism.

\section{Acknowledgment}

First of all, I would like to thanks to faculty of social and political sciences of Universitas Airlangga for providing a great opportunity to students. I also want to acknowledge my supervisor Prof Bagong and co-supervisor Vinsensio Dugis, Ph.D., for their expert advice. This paper is part of my Ph.D. research. I would like to thanks my best friend's doctoral candidate Muhammad Saud for his guidance while writing this paper.

\section{References}

Acharya A, Bukhari SAAS, \& Sulaiman S (2009) Making money in the Mayhem: Funding Taliban insurrection in the Tribal Areas of Pakistan. Studies in Conflict \& Terrorism 32 (2):95-108. https://doi.org/10.1080/10576100802628314.

Afghan Zarizha (2015) Taliban strengthening links to organized crime in Afghanistan: UN report, 10 February. [Accessed 29 July 2019]. https://www.afghanzariza.com/2015/02/10/talibanstrengthening-links-to-organized-crime-in-afghanistan-un-report.

Antonoglou Y (2018) Organized Crime Vs. Terrorism are They Converging? Vocal Europe, 12 February. [Accessed 25 August 2019]. https://www.vocaleurope.eu/organized-crime-vsterrorism-are-they-converging/. 
Bergen P \& Footer L (2008) Defeating the attempted global Jihadist insurgency: Forty steps for the next president to pursue against Al-Qaeda, like-minded groups, unhelpful state actors, and radicalized sympathizers. The ANNALS of the American Academy of Political and Social Science 618 (1):232-247. https://doi.org/10.1177/0002716208317785.

Blua A (2004) Central Asia: Is the IMU still a threat to regional security? Radio Free Europe Radio Liberty, 23 January. [Accessed 13 June 2019]. https://www.rferl.org/a/1051302.html.

Crilly R (2013) Senior Pakistan Taliban figure explains why they shot Malala Yousafzai, The Telegraph, 17 July. [Accessed 5 June 2019]. https://www.telegraph.co.uk/news/worldnews/ asia/pakistan/10185660/Senior-Pakistan-Taliban-figure-explains-why-they-shot-MalalaYousafzai.html.

Daase C (2010) Terrorism and Organized Crime: One or Two Challenges? In: Benedek W, Daase C, Dimitrijević V, \& van Duyne P (eds). Transnational Terrorism, Organized Crime and Peace-Building. London: Palgrave Macmillan. 54-65. https://doi.org/10.1057/97802302 814794.

Dishman C (2001) Terrorism, crime, and transformation. Studies in Conflict \& Terrorism 24 (1):4358. https://doi.org/10.1080/10576100118878.

Dishman C (2005) The leaderless nexus: When crime and terror converge. Studies in Conflict \& Terrorism 28 (3):237-252. https://doi.org/10.1080/10576100590928124.

Durnagol E (2009) The role of drugs in terrorism and organized crime. Ankara Bar Review 2 (2):46-80.

Felbab-Brown V (2010) The Drug-Conflict Nexus in South Asia: Beyond Taliban Profits and Afghanistan. In: Gartensein-Ross D \& May CD (eds). The Afghanistan-Pakistan Theater: Militant Islam, Security \& Stability. Washington DC: Foundation for Defense of Democracies. 90-112.

Gilmore J (2011) A kinder, gentler counter-terrorism: Counterinsurgency, human security, and the war on terror. Security Dialogue 42 (1):21-37. https://doi.org/10.1177/0967010610393390.

Giustozzi A (2009) Decoding the New Taliban: Insights from the Afghan Field. London: Hurst Publisher.

Goepner EW (2018) War State, Trauma State: Why Afghanistan Remains Stuck in Conflict. Washington DC: Cato Institute.

Hammes TX (2005) War evolves into the fourth generation. Contemporary Security Policy 26 (2):189-221. https://doi.org/10.1080/13523260500190500.

Hutchinson S \& O'Malley P (2007) A crime-terror nexus? Thinking on some of the links between terrorism and criminality. Studies in Conflict Terrorism 30 (12):1095-1107. https://doi. org/10.1080/10576100701670870.

Innes MA (2007) Cracks in the System: Sanctuary and Terrorism after 9/11. In: Innes MA (ed). Denial of Sanctuary. USA: Praeger.

Khattak D (2012) The complicated relationship between the Afghan and Pakistani Taliban. Combatting Terrorism Center at West Point 5 (2). [Accessed 07 June 2019]. https://www.ctc.usma.edu/ the-complicated-relationship-between-the-afghan-and-pakistani-taliban/.

Kilcullen D (2006) Counter-insurgency redux. Survival: Global Politics and Strategy 48 (4):111-130. https://doi.org/10.1080/00396330601062790.

Kilcullen D (2009) The Accidental Guerilla: Fighting Small Wars in the Midst of a Big One. London: Oxford University Press.

Korteweg R (2008) Black holes: On terrorist sanctuaries and governmental weakness. Civil Wars 10 (1):60-71. https://doi.org/10.1080/13698240701835482.

Lyman M \& Potter GW (2011) Organized crime, $5^{\text {th }}$ ed. USA: Pearson Education Inc.

Makarenko T (2004) The crime-terror continuum: Tracing the interplay between transnational organized crime and terrorism. Global Crime 6 (1):129-145. https://doi.org/10.1080/17440 57042000297025 . 
Makarenko T \& Mesquita M (2014) Categorizing the crime-terror nexus in the European Union. Global Crime 15 (3-4):259-274. https://doi.org/10.1080/17440572.2014.931227.

Meierrieks D \& Schneider F (2016) The short-and long-run relationship between the illicit drug business and terrorism. Applied Economics Letters 23 (18):1274-1277. https://doi.org/10.10 80/13504851.2016.1150942.

Nizam, Z (2018) Collusion of terrorist groups with organized crime Groups, Daily Outlook Afghanistan, 10 February. [Accessed 05 July 2019]. http://www.outlookafghanistan.net/ topics.php?post_id=20146

Peters G (2009) How Opium Profits the Taliban. Vol. 31 No. 19-62. Washington DC: United States Institute of Peace.

Peters G \& Rassler D (2010) Crime and insurgency in the tribal areas of Afghanistan and Pakistan. Combating Terrorism Center at West Point. [Accessed 20 June 2019]. https://ctc.usma.edu/ crime-and-insurgency-in-the-tribal-areas-of-afghanistan-and-pakistan/.

Peters G (2012) Haqqani Network Financing: The Evolution of an Industry. Combating Terrorism Center at West Point. [Accessed 17 June 2019]. https://ctc.usma.edu/haqqani-networkfinancing/.

Rashid A (2010) Afghanistan and Pakistan: Past Mistakes, Future Directions? The Tanner Lectures on Human Values. Brasenose College, Oxford on 12-13 February.

Reese JY (2016) Financing the Taliban. In: Freeman M (ed). Financing Terrorism. UK: Routledge. 103-120.

Reitano T, Clarke CP, \& Adal L (2017) Examining the Nexus between Organized Crime and Terrorism and its implications for EU Programming. CT Morse Counter-Terrorism Monitoring, Reporting, and Support Mechanism.

Roggio B (2008) Pakistan frees formers Guantanamo prisoner, Afghan Taliban Commander, The Long War Journal, 20 May. [Accessed 27 August 2019]. http://www.longwarjournal.org/ archives/2008/05/pakistan_frees_forme.php.

Rollins J \& Wyler LS (2013) Terrorism and Transnational Crime: Foreign Policy Issues for Congress. Washington DC: Congressional Research Service.

Sanderson TM (2004) Transnational terror and organized crime: Blurring the lines. SAIS Review of International Affairs 24 (1):49-61. https://doi.org/10.1353/sais.2004.0020.

Sarwari A \& Crews RD (2009) 'Epilogue: Afghanistan and the Pax Americana'. In: Crews RD \& Tarzi A (eds). The Taliban and the Crisis of Afghanistan. Cambridge: Harvard University Press. 347-349.

Sang-Hun C (2007) Freed by Taliban, 19 South Korean Hostages Will Face Relief and Anger Back Home, The New York Times, 2 September. [Accessed 03 June 2019]. https://www.nytimes. com/2007/09/02/world/asia/02hostage.html.

Schmidt AP (2005) Links between terrorism and drug trafficking: A case of narco-terrorism? In: International Summit on Democracy, Terrorism and Security, 27 January, Madrid.

Shelley L \& Picarelli JT (2002) Methods not motives: Implications of the convergence of international organized crime and terrorism. Police Practice and Research 3 (4):305-318. https://doi.org/ $10.1080 / 1561426022000032079$.

Shelley L \& Picarelli JT (2005) Methods and motives: Exploring links between transnational organized crime and international terrorism. Trends in Organized Crime 9 (2):52-67. https:// doi.org/10.1007/s12117-005-1024-x.

Stares PB (1996) Global Habit: The Drug Problem in a Borderless World. Washington DC: Brookings Institution Press.

UNODC (2009) Addiction, Crime, and Insurgency: The Transnational Threat of Afghan Opium. Vienna: UNODC Publications. [Accessed 11 July 2019]. https://www.unodc.org/documents/ data-and-analysis/Afghanistan/Afghan_Opium_Trade_2009_web.pdf. 
UNODC (2011) Capturing the Faces of the Drug Trade in Afghanistan, UNODC, 5 May. [Accessed 29 July 2019] https:/www.unodc.org/unodc/en/frontpage/2011/May/capturing-the-faces-ofthe-drug-trade-in-afghanistan.html.

Wang P (2010) The crime-terror nexus: Transformation, alliance, convergence. Asian Social Science 6 (6):11-20. https://doi.org/10.5539/ass.v6n6p11.

Weir J \& Azamy H (2015) The Taliban's Transformation from Ideology to Franchise, Foreign Policy, 17 October. [Accessed 04 June 2019]. https://foreignpolicy.com/2014/10/17/the-talibanstransformation-from-ideology-to-franchise/.

Williamson JG (1996) Globalization, convergence, and history. The Journal of Economic History. 56 (2):277-306. doi: 10.1017/S0022050700016454. 